\title{
The Two Brothers: an enlightening study of ancient Egyptian teeth
}

\section{DOI:}

10.1038/s41415-019-0149-2

\section{Document Version}

Accepted author manuscript

Link to publication record in Manchester Research Explorer

\section{Citation for published version (APA):}

Forshaw, R. (2019). The Two Brothers: an enlightening study of ancient Egyptian teeth. British Dental Journal, 226(7), 518-524. https://doi.org/10.1038/s41415-019-0149-2

\section{Published in:}

British Dental Journal

\section{Citing this paper}

Please note that where the full-text provided on Manchester Research Explorer is the Author Accepted Manuscript or Proof version this may differ from the final Published version. If citing, it is advised that you check and use the publisher's definitive version.

\section{General rights}

Copyright and moral rights for the publications made accessible in the Research Explorer are retained by the authors and/or other copyright owners and it is a condition of accessing publications that users recognise and abide by the legal requirements associated with these rights.

\section{Takedown policy}

If you believe that this document breaches copyright please refer to the University of Manchester's Takedown Procedures [http://man.ac.uk/04Y6Bo] or contact uml.scholarlycommunications@manchester.ac.uk providing relevant details, so we can investigate your claim.

\section{OPEN ACCESS}




\title{
The Two Brothers: an enlightening study of
}

\section{Ancient Egyptian teeth}

\section{Roger Forshaw ${ }^{1}$}

\begin{abstract}
The 'Two Brothers', two 4,000-year-old Egyptian mummies, were discovered buried alongside each other in an ancient Egyptian tomb in 1907, and were later relocated to the Manchester Museum. The hieroglyphic inscriptions on the coffins indicate that the mummies, Nakht-ankh and Khnum-nakht were brothers but when the mummies were unwrapped and investigated in 1908, the skeletal morphologies were found to be quite different, suggesting an absence of family relationship. In 2017, their teeth were re-examined and similar to most ancient Egyptian teeth, they display evidence of excessive tooth wear but there is little indication of carious lesions. Khnum-nakht presents the rare developmental disorder of fusion of the left maxillary incisor and gemination of the right incisor, probably the earliest recorded instance of this irregularity. Analysis of the DNA from their molar teeth has been able to shed some light on the longstanding question of the kinship of the Two Brothers.
\end{abstract}

\section{Introduction}

Early in 2018 the media showed considerable interest in the results of the recent DNA investigations into the Two Brothers, two ancient Egyptian mummies that form part of the collection at the Manchester Museum. Over the last century, the two mummified bodies, Khnum-nakht and Nakht-ankh, have been the subject of a number of detailed studies, including investigations of their teeth and skeletal morphology. More recently, their teeth have been reexamined and DNA obtained from their molar teeth has been sequenced in an attempt to resolve the perplexing question of a possible familial relationship between them.

\footnotetext{
${ }^{1}$ R J Forshaw LDS RCS(ENG), BChD, DGDP(UK), MSC, PhD

Honorary Lecturer, KNH Centre for Biomedical Egyptology, Faculty of Biology, Medicine and Health, The University of Manchester/Dental Surgeon

Correspondence to: Roger Forshaw

Email: Roger.Forshaw@manchester.ac.uk
} 


\section{(1) HISTORICAL BACKGROUND AND EARLY INVESTIGATIONS}

Discovery of the tomb

The mummies were discovered in 1907 interred alongside each other in an undisturbed Middle Kingdom (1985-1773 BC) tomb at Deir Rifeh, a village 250 miles south of Cairo (Fig. 1). The tomb was found by an Egyptian workman called Erfal, working under the supervision of the eminent British Egyptologists, Flinders Petrie and his associate Ernest Mackay. The complete contents of the tomb, including their coffins and grave goods, were transferred to Manchester in 1908, and remained intact as a group rather than being divided among different museum collections, as was usual at that time. ${ }^{1}$

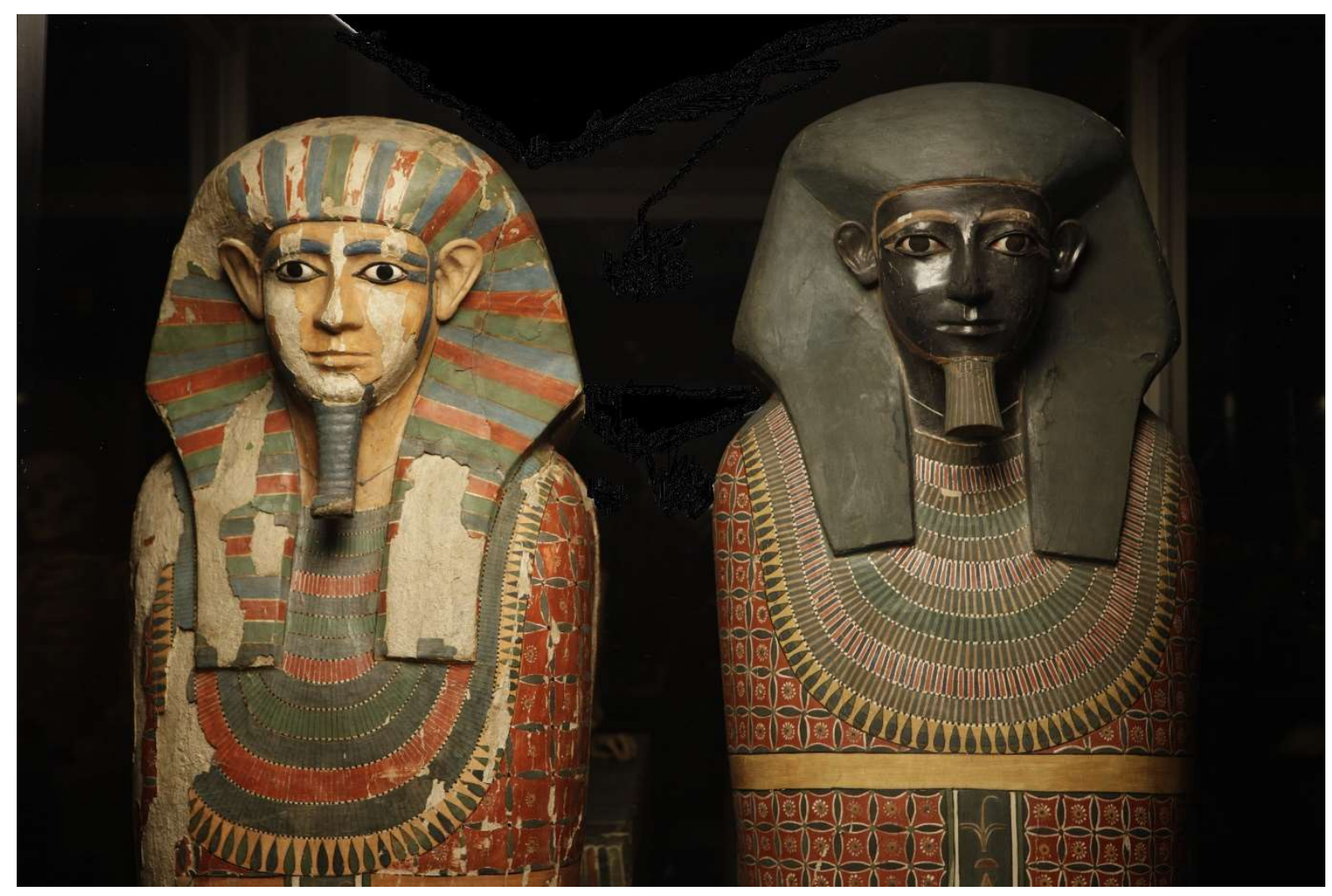

Fig. 1 The 'Two Brothers' inner 'body' coffins - Khnum-nakht (left) and Nakht-ankh (right). They were interred along-side each other without wives and offspring suggesting that neither were married.

Reproduced with permission from the Manchester Museum, University of Manchester

Upon arrival in Manchester in 1908, the mummies were unwrapped by the UK's first female Egyptologist, Margaret Murray, who was also the first curator of the Egyptian collection at the Manchester Museum (Fig. 2). In an important development in scientific study, Margaret 
Murray assembled a multi-disciplinary team of researchers to examine their bodies in what was one of the earliest full-scale scientific investigations carried out on mummies. ${ }^{2}$

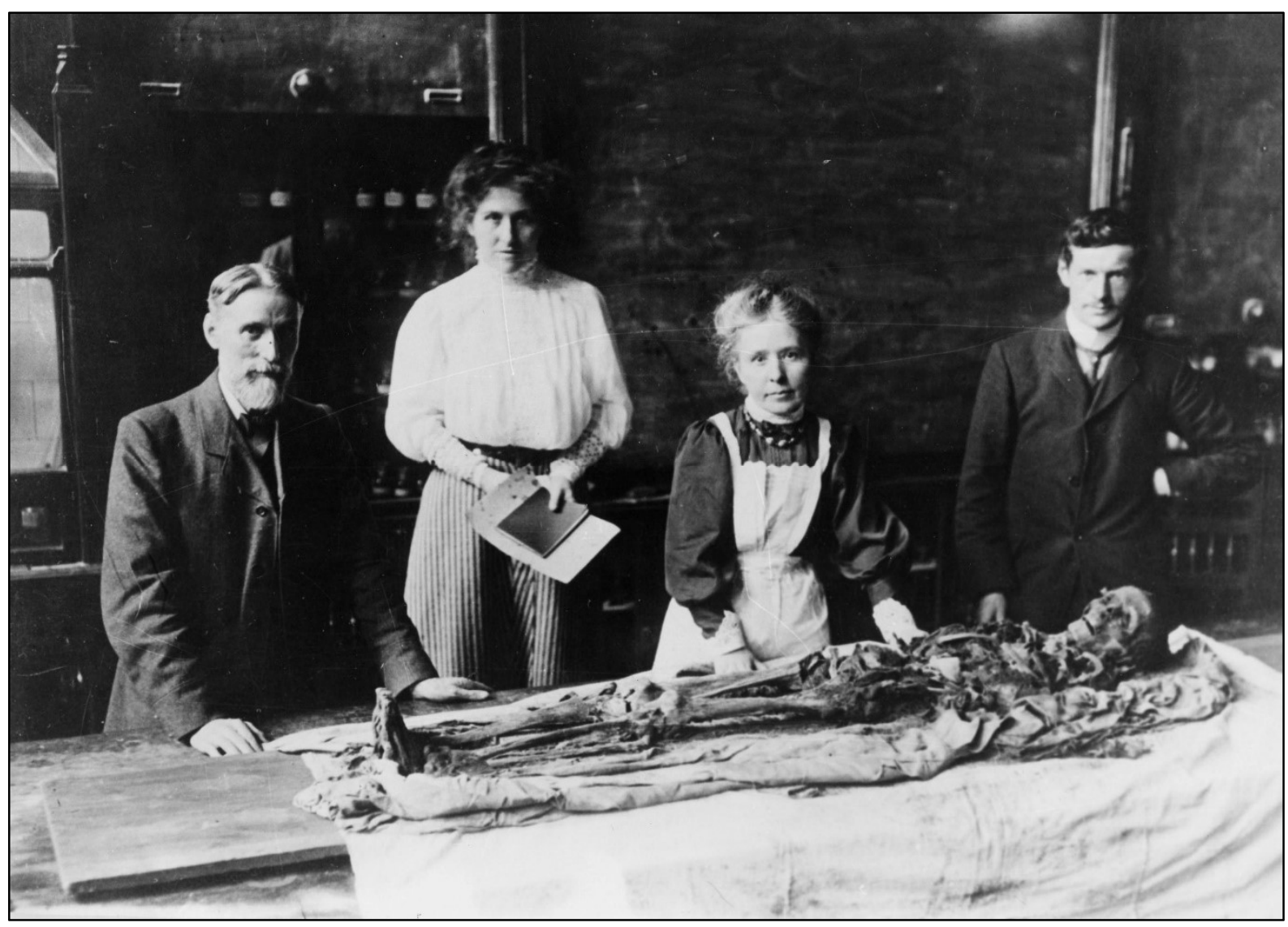

Fig. 2 Margaret Murray and her team unwrapping the mummy of Khnum-nakht in the chemistry lecture theatre, the University of Manchester, 6 May 61908. Reproduced with permission from the Manchester Museum, University of Manchester

\section{Skeletal Investigation}

John Cameron, a medical member of the team, undertook the anatomical and pathological examination. He concluded that Nakht-ankh was at least 60 when he died, and with the average life expectancy in ancient Egypt being around thirty-five, Nakht-ankh had experienced a relatively long life. ${ }^{3}$ Khnum-nakht, on the other hand, probably died in his forties. Stature for both of the mummies was estimate at about 1.6 metres and they both displayed evidence of osteoarthritis in the vertebrae. The teeth were briefly commented on, particularly the fused left maxillary incisors of Khnum-nakht which was likened at the time to a 'huge tusk'. 

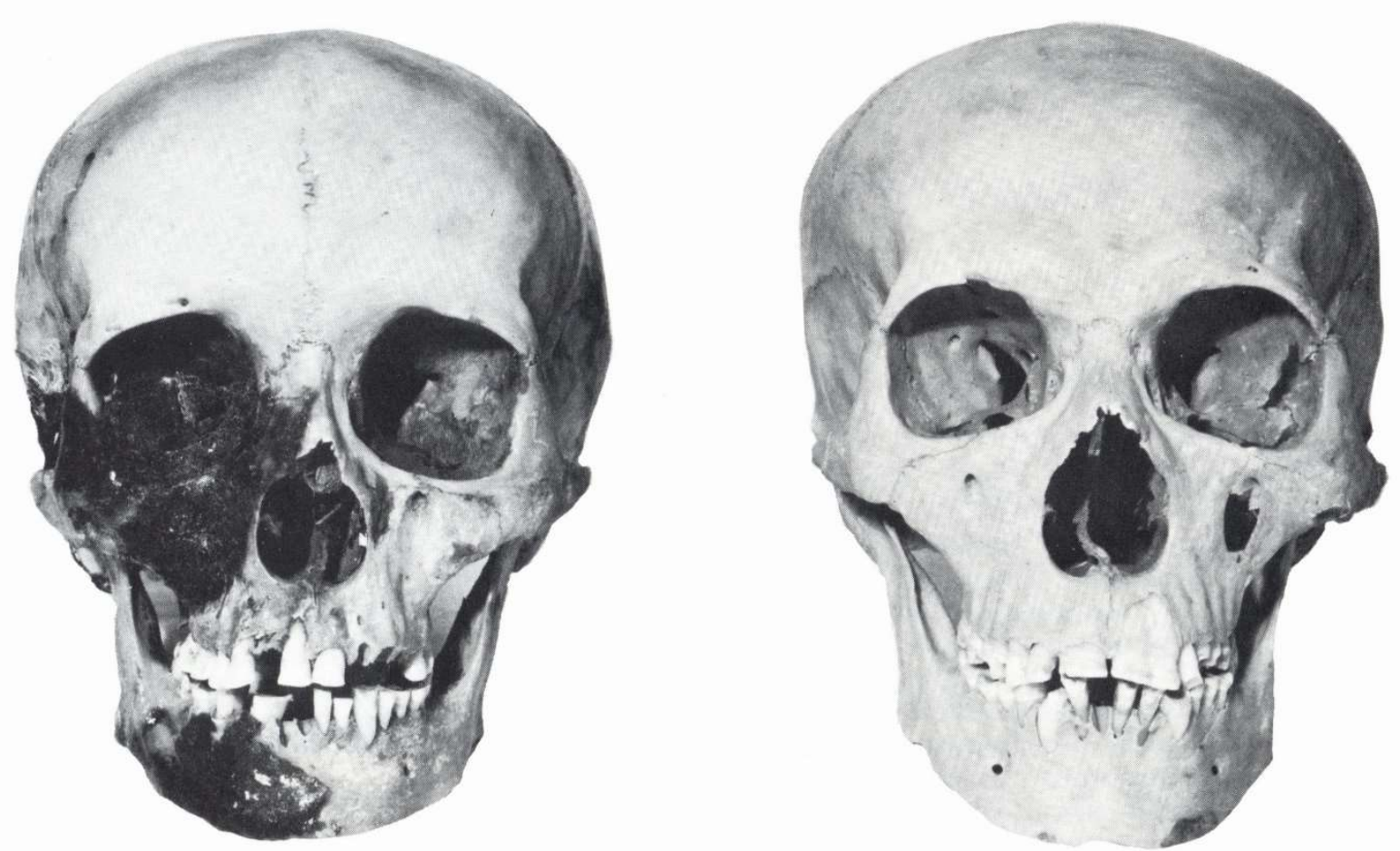

Fig. 3 Skulls of the Two Brothers, Nakht-ankh (left) and Khnum-nakht (right). Reproduced with permission from Manchester University Press

The skulls were found to be strikingly different. with that of Khnum-nakht being markedly prognathous and Nakht-ankh orthognathous. The protrusive nature of the maxilla and mandible of Khnum-nakht resulted in the conclusion that he was of black African descent, possibly Nubian. This divergence in skeletal morphology was found to apply to many of the other anatomical features evident in the skulls (Fig. 3). The shape and size of the calvarium, and the dimension of the zygomatic bones, orbits and nasal cavities were all recorded as displaying a marked metric variation. This almost complete lack of resemblance also extended to the other bones of the skeleton and led to the conclusion that it was unlikely that they were directly related. Cameron commented that: 'these differences are so pronounced that it is almost impossible to convince oneself that they belong to the same race, far less to the same family'. In the 1970s radiological examinations of the skeletons, unavailable at the time of the original investigation, were undertaken together with facial reconstructions, which again highlighted the variation in cranial morphology. ${ }^{4}$

Inheritance plays a significant role in the determination of craniofacial morphology. The conclusion is based on cephalometric and anthropometric comparisons between identical and 
fraternal twins, among siblings, and between parents and their offspring. ${ }^{5,6}$ These familial studies of craniofacial shape show a moderate to high degree of heritability for a substantial set of craniofacial traits including facial height and width, while local facial features such as the orbits, nose, jaw, and teeth demonstrate a high heritability. ${ }^{7,8,9}$ Cranial form is a complex interaction of intrinsic (such as hormones and genetic) and extrinsic (mainly environmental and mechanical) factors. ${ }^{10}$ Taking into account the dental developmental anomalies as described later in this article, it is quite likely that the cranial development of one or both individuals may have been perturbed, leading to pronounced differences in adult cranial form. Therefore, the influence of inheritance on craniofacial traits cannot, by itself, be used to assess a familial relationship, as was suggested at the time of the 1908 investigation.

\section{Hieroglyphic evidence}

The hieroglyphic inscriptions on the coffins indicate that the mother of Khnum-nakht and Nakht-ankh was named Khnum-Aa and that they were the sons of an unnamed local governor. There is a variation in the way the patrilineal descent is specified for both sons, in that both the father and grandfather of Khnum-nakht are identified as local governors, whereas the text states that only Nakht-ankh's father held that position. ${ }^{1}$ The slight variation in inscriptional evidence, together with the anatomical divergence, has been interpreted as an absence of family relationship and has led to the conclusion that either their mother had had two husbands or that one or both of the sons were adopted. The original examination had concluded that Nakht-ankh was aged about 60 when he died and Khnum-ankh approximately 40, although today it is recognised that the determination of age in adults by traditional morphological methods is often imprecise. ${ }^{11,12}$

\section{Coffins}

The body coffins of the Two Brothers have different coloured faces with that of Nakht-ankh being painted black, while Khnum-nakht's face has a yellowish-white face. If these colours were actually intended to indicate their skin tones, then it would appear that the bodies were placed in the wrong coffins, as it is Khnum-nakht who was identified by his cranial features as being of African descent. However, there is no supporting evidence from other burials to suggest that coffins of non-royal persons ever represented the individual physical characteristics of the owner. One explanation is that the black face on Nakht-ankh's coffin was intended to symbolise the appearance of the god Osiris, whom the dead owner had now 
become. Osiris is frequently shown with a black or green face to indicate that he represented the black, fertile soil of Egypt and the annual rebirth of the vegetation. ${ }^{1}$

\section{DNA studies}

More recently they have been the subject of two separate DNA investigations, in an attempt to revisit this question of possible familial relationship. Both investigations were able to obtain mitochondrial DNA from the surviving desiccated soft tissue of the two mummies. Mitochondrial DNA specifies whether individuals share the same haplotype. If they have the same mother, or same grandmother on the maternal side, they will have the same haplotype, whereas if they have different mothers then they are likely to have different haplotypes. The two analyses produced conflicting results with the 2005 research by Smyth ${ }^{13}$ indicating a probability of a maternal relationship, whereas the 2014 analysis by Matheson et al. ${ }^{14}$ found no apparent evidence of a maternal relationship.

\section{(2) The 2017 investigations of the teeth of the Two Brothers}

\section{Overview}

In 2017 , the teeth were re-examined by the author and the latest DNA technique, nextgeneration sequencing (NGS), was utilised by Konstantina Drosou of the Manchester Institute of Biotechnology in the latest investigation of kinship of the Two Brothers.

An examination of ancient teeth is particularly important in archaeological studies as it can provide considerable information related to the life style and dietary habits of our ancestors. Visual and radiological studies can identify palaeopathological lesions useful in identifying dietary patterns. Plant microfossils and non-dietary debris are able to be isolated from calculus and can be identified using light microscopy, again providing dietary evidence as well as cultural and environmental data. More recent analytical techniques, such as stable isotope analysis, can assist in tracing the geographic origins and migrations of peoples. In addition, there are a number of anthropological questions that can potentially be addressed by DNA analysis, such as the determination of sex when conventional identification methods are impossible, as well as the origin, familial relationships and movements of populations. ${ }^{15}$

\section{Teeth present}

Khnum-nakht possessed a full dentition during life, but a number of teeth have since been lost in post-mortem handling. For Nakht-ankh, apart from the right maxillary lateral incisor all of 
the teeth were present during life, although again a number have since fallen from their sockets. The extensive loss of labial and buccal bone around the socket of this missing lateral incisor and its adjacent teeth, suggest that its premature loss may be due to trauma, perhaps an accident or interpersonal violence.

\section{Tooth wear}

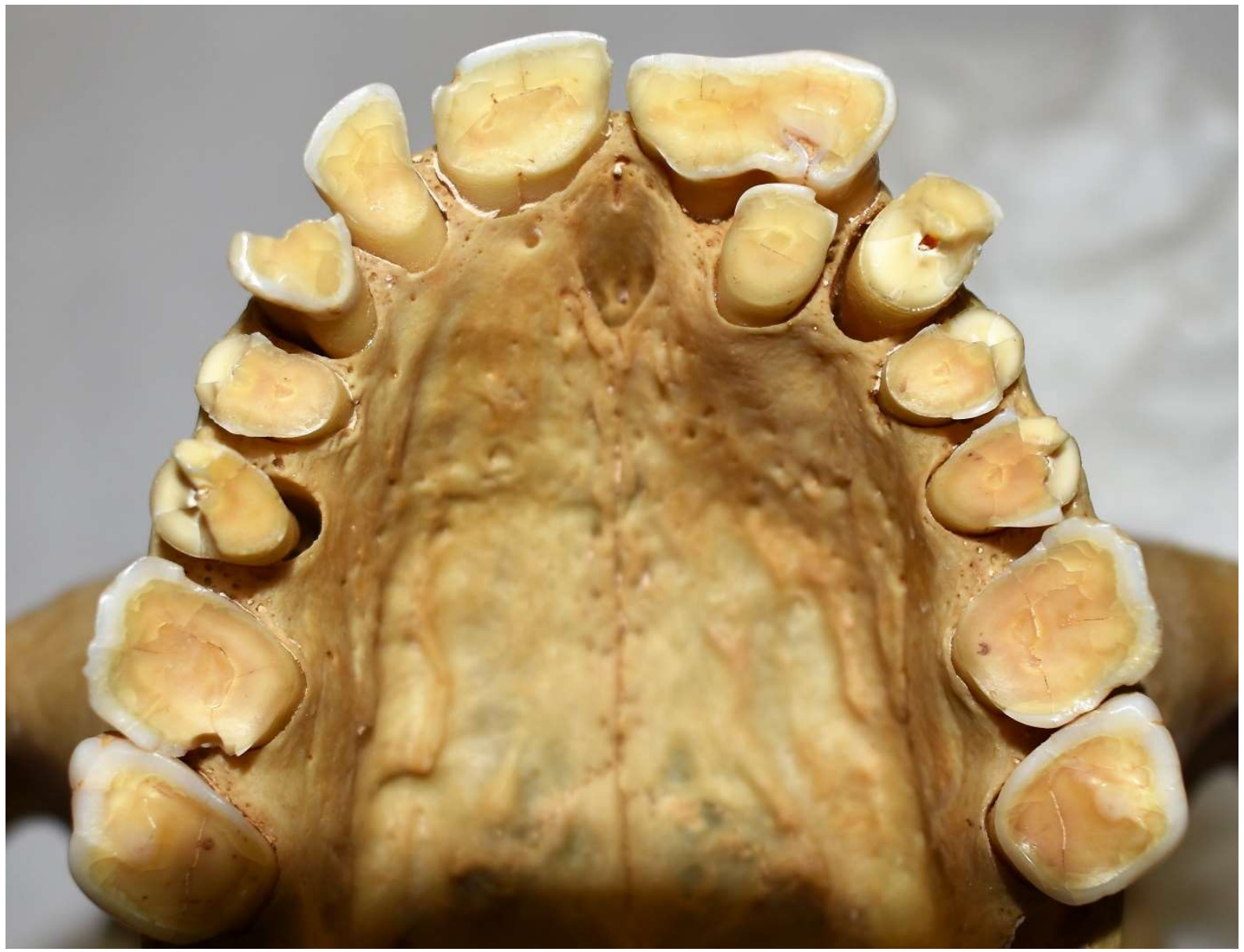

Fig. 4 Teeth of Khnum-nakht showing extensive tooth wear. Reproduced with permission from the Manchester Museum, University of Manchester

Similar to most ancient Egyptian teeth those of the Two Brothers show excessive wear, a condition caused by the consumption of a coarse diet throughout their lives (Fig. 4). This widespread condition has been demonstrated in the majority of ancient Egyptian dentitions throughout the dynastic period. ${ }^{16,17,18,19,20}$ It has often been categorised as attrition, but analysis of the problem reveals that attrition was not the sole agent responsible for the loss of tooth tissue. Adulteration of the food by significant numbers of inorganic particles resulted in an additional element of abrasion. This particulate matter was found mainly in the bread, the staple 
food of the ancient Egyptians, and was present largely as a result of contamination of the grain by wind-blown sand. Other factors such as the use of flint-tooth sickle harvesting tools, grinding corn with soft sandstone implements, and baking the bread on the outside of stone ovens would have caused further extrinsic fragments to infiltrate the grain and bread.

Rather than attrition, tooth wear with components of both attrition and abrasion is perhaps a better definition for this condition. ${ }^{21}$ The tooth wear increased with the age of the individual and varied from a slight polishing of the cusps to almost complete loss of crown structure. Often it was so extensive it occurred at a faster rate than the odontoblasts were able to lay down secondary dentine, resulting in pulpal exposure, necrosis of the pulp and subsequent apical infection. $^{20}$

\section{Caries}

Only one small carious occlusal cavity is evident in the right mandibular third molar of Nakhtankh, while the teeth of Khnum-nakht are caries free. The lack of caries is a common finding in the extant dentitions from ancient Egypt and other early societies. This is due to the lack of fermentable carbohydrates in ancient diets coupled with the fibrous abrasive nature of the food, which would have tended to inhibit the retention of plaque on the tooth surface and thus reduce its susceptibility to carious attack. ${ }^{22}$ Tooth wear was also a factor since occlusal wear would have eliminated pits and fissures, whilst interproximal wear would have produced flattened tooth contacts, both creating a more difficult environment for plaque and caries to proliferate in. 19

\section{Developmental defects}

The maxillary central incisors of Khnum-nakht are abnormally large with the left incisor displaying a vertical groove extending from the incisal edge to the root apex (Fig. 5). The teeth demonstrate the rare developmental disorder of fusion of the left incisor and gemination of the right incisor. This instance of gemination and fusion within the same individual, dating back nearly 4,000 years is the earliest known recorded example of such an anomaly.

Gemination and fusion are developmental anomalies of tooth shape, which affect both the permanent and primary dentitions..$^{21,23,24,25,26}$ Gemination is recognised as an unsuccessful attempt by a single tooth germ to divide by invagination during the proliferative stage of dental development. This results in a large single tooth whose appearance varies from a groove or 
depression to two crowns joined together, indicating the abortive attempt of the teeth to be completely separate. Geminated teeth have a single pulp chamber and usually a large single root and root canal, as is the case with Khnum-nakht (Fig. 6).
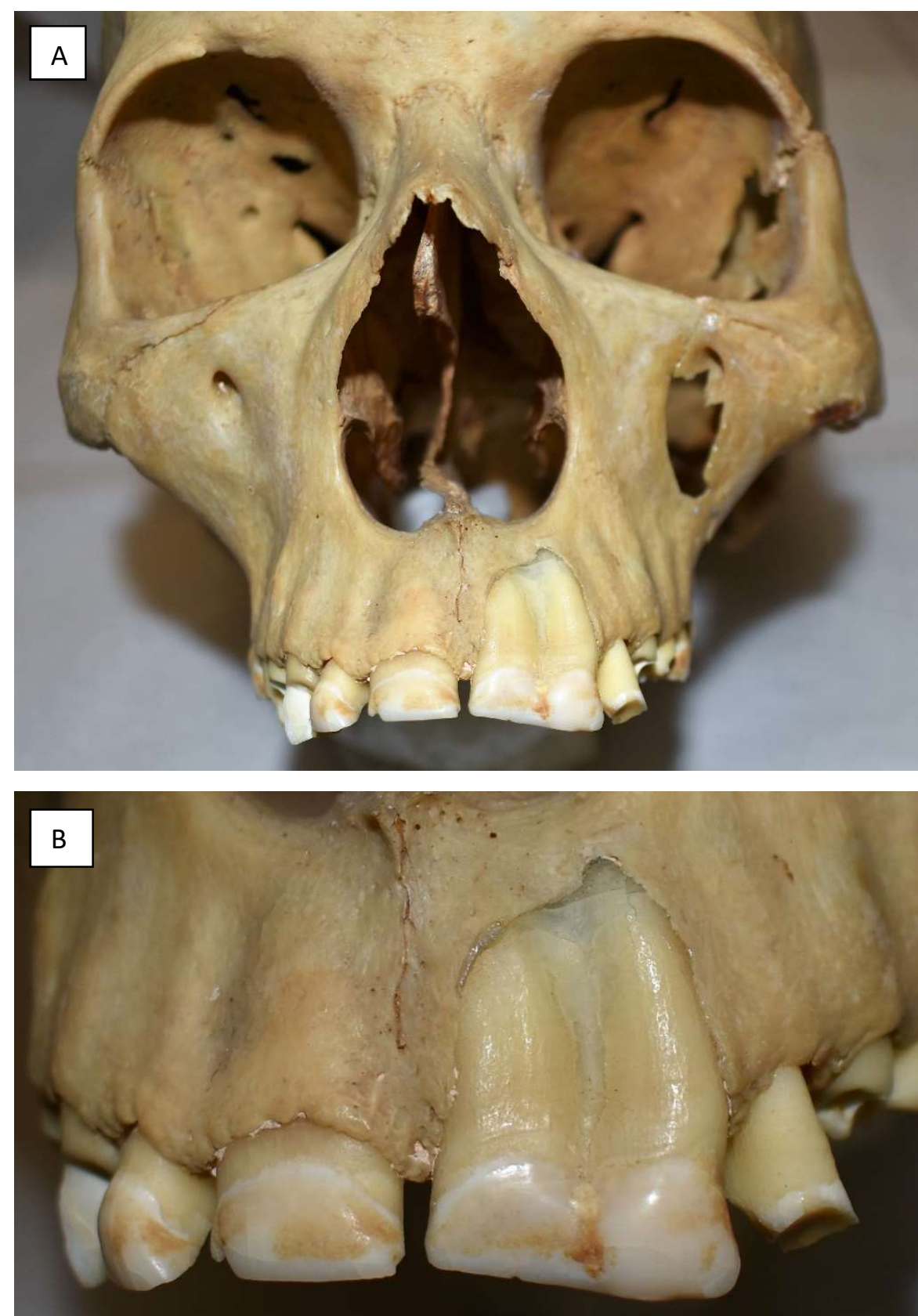

Fig. 5 a) Skull of Khnum-nakht. The central incisors display the rare developmental abnormality of fusion (right) and gemination (left) within the same arch; b) Close-up of the central incisors of Khnum-nakht. Reproduced with permission from the Manchester Museum, University of Manchester 


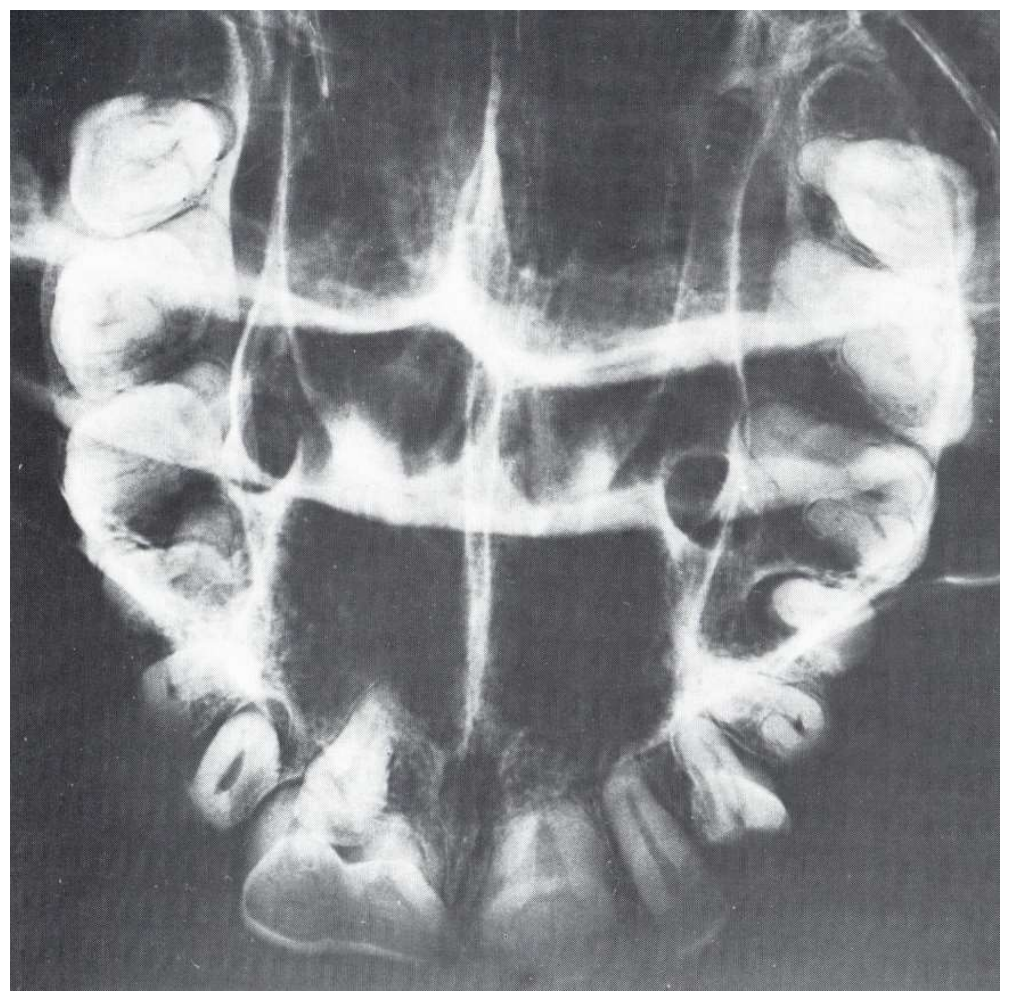

Fig. 6 Occlusal radiograph of the maxillary teeth of Khnum-nakht. The left central incisor is fused with a supernumary tooth and the lateral incisor is instanding due to lack of space within the dental arch. The right central incisor is geminated. Reproduced with permission from Manchester University Press

Fusion is a union of two separate tooth germs at some stage in their development and is suggested to be the result of some physical force or pressure. The fusion may be partial or total depending upon the stage of tooth development at the time of union, and so one tooth may be present with only one pulp chamber and a merging of dentine and/or enamel, as in gemination, or there may be two separate pulp chambers with two roots or two canals in a single root. In the case of Khnum-nakht the left central incisor shows separate pulp chambers and separate roots (Fig. 6).

Fusion can occur between teeth of the same dentition or mixed dentitions, and between normal and supernumerary teeth. ${ }^{27,28}$ Supernumerary teeth are often atypical and so fusion between a supernumerary and a normal tooth will generally show differences in the two halves of the joined crown, whereas in examples of gemination the two halves of the joined crown are commonly mirror images, as with Khnum-nakht. Despite the considerable number of cases reported in the literature, the differential diagnosis between these abnormalities can on 
occasions be difficult, particularly when supernumerary teeth are present, and so diagnosis requires careful visual and radiographic examination. ${ }^{29,30}$

When fusion occurs, the total number of teeth in the dental arch will be reduced unless a supernumerary tooth is involved. With Khnum-nakht the maxillary left central incisor has fused with a supernumerary tooth, and the left lateral incisor is palatally displaced due to lack of space within the dental arch, resulting in no reduction in the number of teeth. Gemination by definition will not reduce the number of teeth present.

The exact causes of these abnormalities are uncertain but gemination is believed to be the result of a disturbance in epithelial-mesenchymal interactions which can markedly disturb tooth development. It is suggested that this may be caused by local metabolic interferences occurring during morpho-differentiation of the tooth germ. Severity of the anomaly depends on the stage of formation of the involved teeth. ${ }^{31}$ With fusion the influence of pressure or physical forces producing close contact between two tooth germs during their development can be a factor. ${ }^{29,30}$ As the aetiology remains unclear, to avoid any confusion, some authors prefer to use the term 'double teeth' which describes the appearance with no implication regarding the cause of this condition. ${ }^{21,32}$

These dental abnormalities are more frequent in the anterior region of the permanent dentition. They do not show a sex predilection but genetic predisposition and racial differences have been cited as contributing factors in both gemination and fusion. ${ }^{24,25,29}$ While the incidence varies in individual reports, for single examples it appears to be approximately $0.5 \%$ in the primary dentition and $0.1 \%$ in the permanent dentition. Bilateral presentation of these conditions is even less common with prevalence estimated at $0.02 \%-0.05 \%$ for both dentitions. ${ }^{25,33,34}$ In both primary and permanent dentitions, fused or geminated teeth may cause functional, aesthetic, caries, periodontal and orthodontic problems. ${ }^{35}$ Apart from the Two Brothers there appears to be no other documented instance of this double developmental abnormality in other ancient specimens.

\section{Ancient DNA investigation}

Teeth are an excellent source of DNA as they are well preserved in the archaeological record, usually surviving long after their supporting structures have deteriorated. Due to their unique composition and location within the mandible and maxilla they are largely shielded from the 
environmental and physical conditions that act to accelerate the processes of post-mortem decomposition and DNA decay. ${ }^{36,37}$ DNA extracted from teeth and particularly the cementum of the teeth, where concentrations are higher, ${ }^{38,39,40}$ is less prone to contamination than DNA extracted from bones. ${ }^{41}$

A recent technique to emerge in this field, next-generation sequencing (NGS), enables hundreds of thousands of short sequences of ancient DNA to be obtained in a single study. This method has increased the amount of DNA sequence data available for analysis from ancient material by several orders of magnitude, and so is now considered far more reliable than earlier techniques such as the polymerase chain reaction. ${ }^{42,43}$ In NGS the technique involves extracting DNA from teeth and then, following hybridization capture of the mitochondrial and $\mathrm{Y}$ chromosome fractions, the DNA is sequenced. ${ }^{44}$

In the 2017 analysis molar teeth that were reasonably firmly attached to the surrounding alveolar bone were selected. This ensured that they belonged to the same individual, and had probably not been previously removed from their sockets, so reducing the risk of contamination. Careful digital manipulation was used to remove the teeth in order to minimise damage to the surrounding bone.

Earlier methods to extract DNA from teeth involved milling and crushing of teeth, a process which destroyed the morphologically informative crown and so rendered them of little or no further use to other investigators, while also damaging rare archaeological resources. ${ }^{45,46}$ The method chosen for this study involved obtaining cementum and dentine from the root of the tooth by the 'reverse root canal technique', which because of its minimally destructive nature preserved the crown intact. ${ }^{41,47,48}$ Increasing sizes of hand files were introduced through the apical foramina into the pulp chambers, a process which was able to obtain 50-70 $\mathrm{mg}$ of hard tooth tissue. The sample obtained by this technique is free from enamel which would have had a diluting effect, as being an acellular material contains no DNA. In addition, the high concentrations of minerals in enamel, particularly calcium, may have complicated the extraction process. ${ }^{49}$ During all these procedures of sampling, tooth preparation and DNA extraction, recommended laboratory and analytical standards were followed to ensure reliable DNA acquisition and detection. ${ }^{44}$ 
The mitochondrial results indicate that both Nakht-ankh and Khnum-nakht belong to mitochondrial haplotype M1a1, suggesting that they had the same mother. However, the M1a1 haplotype is estimated to have been present in around $6-7 \%$ of the population in ancient Egypt ${ }^{50,51}$ so there is a small possibility that the two individuals inherited the same haplotype entirely by chance. Nevertheless, the probable relatedness as indicated by the DNA results is consistent with the common maternal name as documented in the inscriptional evidence, and it therefore seems very probable that both individuals were the sons of Khnum-Aa. The results of the Y chromosome sequences were less complete but showed variations between the two mummies, suggesting that Nakht-ankh and Khnum-nakht had different fathers. ${ }^{45}$

\section{Conclusion}

The results of the examination of the teeth of two ancient Egyptian mummies carried out at the Manchester Museum and the Manchester Institute of Biotechnology indicated not only extensive tooth wear and a lack of carious lesions, common findings in ancient Egyptian teeth, but also the extremely rare double developmental disorder of gemination and fusion; perhaps the earliest recorded example of such an abnormality. In addition, ancient DNA was successfully extracted from their molar teeth, the first analysis of Egyptian mummies to successfully use the typing of both mitochondrial DNA, which comes from the mother, and Y chromosomal DNA from the father. The DNA results thus add weight to the ancient inscriptional evidence supporting a familial relationship between the Two Brothers.

After a number of scientific studies and considerable speculation, ancient teeth have been able to furnish further information on the kinship of these two ancient Egyptians who lived some 4,000 years ago in the Nile valley, a quandary that has perplexed Egyptologists for over a hundred years.

\section{Bibliography}

\footnotetext{
${ }^{1}$ David R A. The Two Brothers: Death and the Afterlife in Middle Kingdom Egypt. Bolton: Rutherford Press, 2007.

${ }^{2}$ Murray M A (ed). The Tomb of Two Brothers. Manchester, London: Sherratt \& Hughes 1910.

${ }^{3}$ Cameron J. The anatomy of the mummies. In Murray M A (ed) The Tomb of Two Brothers. pp 33-47. Manchester: Sherratt \& Hughes, 1910.

${ }^{4}$ David R A (ed). The Manchester Museum Mummy Project. Manchester: Manchester University Press, 1979.

${ }^{5}$ Kohn L A P. The role of genetics in craniofacial morphology and growth. Annu Rev Anthropol 1991; 20: 261278.

${ }^{6}$ Roosenboom J, Hens G, Mattern B C, Shriver M D, Claes P. Exploring the underlying genetics of craniofacial morphology through various sources of knowledge. Biomed Res Int 2016; 2016: 3054578.
} 
${ }^{7}$ Naini F B, Moss J P. Three-dimensional assessment of the relative contribution of genetics and environment to various facial parameters with the twin method. Am J Orthod Dentofacial Orthop 2004; 126: 655-665.

8 Johannsdottir B, Thorarinsson F, Thordarson A, Magnusson T E. Heritability of craniofacial characteristics between parents and offspring estimated from lateral cephalograms. Am J Orthod Dentofacial Orthop 2005; 127: 200-207.

${ }_{9}^{9}$ Martínez-Abadías N, Esparza M, Sjøvold T, González-José R, Santos M, Hernández M. Heritability of human cranial dimensions: comparing the evolvability of different cranial regions. J Anat 2009; 214: 19-35.

${ }^{10}$ Larsen C S. Bioarchaeology: Interpreting Behavior from the Human Skeleton. Cambridge: Cambridge University Press, 1997.

${ }^{11}$ Mays S. The Archaeology of Human Bones. 2nd ed. pp 40-90. Abingdon: Routledge, 2010.

12 Villa C, Lynnerup N. Age estimation of skeletal remains: principal methods. Research and Reports in Forensic Medical Science 2014; 4: 3-9.

${ }^{13}$ Smyth K. Analysis of Mitochondrial DNA from Mummies Nekht-Ankh and Khnum-Knakht. Unpublished MSc Dissertation. Manchester: University of Manchester, 2005. MSc Dissertation.

${ }_{14}$ Matheson C D, David R A, Spigelman M, Donoghue H D. Molecular confirmation of Schistosoma and family relationship in two ancient Egyptian mummies. In Gill-Frerking H, Rosendahl W, Zink A R. (eds) Yearbook of Mummy Studies 2. pp 39-47. Munich: Friedrich Pfeil, 2014.

${ }^{15}$ Forshaw R J. Dental indicators of ancient dietary patterns: dental analysis in archaeology. Br Dent J 2014; 216: 529-535.

${ }^{16}$ Ruffer M A. A study of abnormalities and pathology of ancient Egyptian teeth. Am J Phys Anthropol 1920; 3: 335-382.

${ }^{17}$ Leek F F. The practice of dentistry in Ancient Egypt. J Egypt Archaeol 1967; 53: 51-58.

${ }^{18}$ Hillson S W. Diet and dental disease. World Archaeol 1979; 11: 147-162.

${ }^{19}$ Harris J E, Ponitz P V, Ingalls B K. Dental health in ancient Egypt. In Cockburn A, Cockburn E, Reyman T A. (eds) Mummies, Disease and Ancient Cultures. 2nd ed. pp. 59-68. Cambridge: Cambridge University Press, 1998.

${ }^{20}$ Forshaw R J. Dental health and disease in ancient Egypt. Br Dent J 2009; 206 (8): 421-424.

${ }^{21}$ Southam J V, Soames J C. Oral Pathology. 4th ed. Oxford, New York: Oxford University Press, 2005.

22 Rateutschak-Pluss E M, Guggenheim B. Effects of a carbohydrate-free diet and sugar substitutes on dental plaque accumulation. J Clin Periodont 1982; 9: 239-251.

${ }^{23}$ Tannenbaum K A, Alling E A. Anomalous tooth development: Case reports of gemination and twinning. Oral Surg Oral Med Oral Pathol 1963; 16: 883-887.

${ }^{24}$ Duncan W K, Helpin M L. Bilateral fusion and gemination: A literature analysis and case report. Oral Surg Oral Med Oral Pathol 1987; 64: 82-87.

${ }^{25}$ Berkovitz B K B, Holland G R, Moxham B J. Oral Anatomy, Histology \& Embryology. 5th ed. Edinburgh: Elsevier, 2017.

${ }^{26}$ Nandini D B, Deepak B S, Selvamani M, Puneeth H K. Diagnostic dilemma of a double tooth: a rare case report and review. J Clin Diagn Res 2014; 8: 271-272.

27 Peyrano A, Zmener O. Endodontic management of mandibular lateral incisor fused with supernumerary tooth. Endod Dent Traumatol 1995; 11: 196-198.

${ }^{28}$ Nunes E, de Moraes I G, de Novaes P M, de Sousa S M. Bilateral fusion of mandibular second molars with supernumerary teeth: Case report. Braz Dent J 2002; 13: 137-141.

29 Jain A A, Yeluri R, Munshi A K. Gemination or fusion? A diagnostic dilemma. Dentistry 2014; 4: 196.

${ }^{30}$ Camargo A J, Arita E S, Watanabe P C A. Fusion or gemination? An unusual mandibular second molar. Int J Surg Case Rep 2016; 21: 73-77.

${ }^{31}$ Grover P S, Lorton L. Gemination and twinning in the permanent dentition. Oral Surg Oral Med Oral Pathol 1985; 59: 313-318.

32 Olivan-Rosas G, López-Jiménez J, Giménez-Prats M J, Piqueras-Hernández M. Considerations and differences in the treatment of a fused tooth. Med Oral 2004; 9: 224-228.

${ }^{33}$ Aguiló L, Gandia J L, Cibrian R, Catala M. Primary double teeth. A retrospective clinical study of their morphological characteristics and associated anomalies. Int J Paediatr Dent 1999; 9: 175-183.

${ }^{34}$ Türkaslan S, Gökçe H S, Dalkız M. Esthetic rehabilitation of bilateral geminated teeth: A case report. Eur J Dent 2007; 1: 188-191.

${ }^{35}$ Sammartino G, Cerone V, Gasparro R, Riccitiello F, Trosino O. Multidisciplinary approach to fused maxillary central incisors: A case report. J Med Case Rep 2014; 8: 398.

${ }^{36}$ Schwartz T R, Schwartz E A. Mieszerski L, McNally L, Kobilinsky L. Characterization of deoxyribonucleic acid (DNA) obtained from teeth subjected to various environmental conditions. J Forensic Sci 1991; 36: 979-990. 


\footnotetext{
${ }^{37}$ Alvarez Garcia A, Muñoz I, Pestoni C, Lareu M V, Rodriguez-Calvo M S, Carracedo A. Effect of environmental factors on PCR-DNA analysis from dental pulp. Int J Legal Med 1996; 109: 125-129.

${ }^{38}$ Alonso A, Andelinović S, Martin P, Sutlović D et al. DNA typing from skeletal remains: Evaluation of multiplex and megaplex STR systems on DNA isolated from bone and teeth samples. Croat Med J 2001; 42: 260-266. ${ }^{39}$ Ricaut F X, Keyser-Tracqui C, Crubézy E, Ludes B. STR-genotyping from human medieval tooth and bone samples. Forensic Sci Int 2005; 151: 31-35.

${ }^{40}$ Damgaard P B, Margaryan A, Schroeder H, Orlando L, Willerslev E, Allentoft M E. Improving access to endogenous DNA in ancient bones and teeth. Sci Rep 2015; 5: 11184.

${ }^{41}$ Gilbert M T P, Bandelt H-J, Hofreiter M, Barnes I. Assessing ancient DNA studies. Trends Ecol Evol 2005; 20: 541-544.

42 Knapp M, Hofreiter M. Next Generation Sequencing of ancient DNA: Requirements, strategies and perspectives. Genes (Basel) 2010; 1: 227-243.

${ }^{43}$ Brown T A, Brown K. Biomolecular Archaeology: An Introduction. Chichester: Wiley-Blackwell, 2011.

${ }^{44}$ Drosou K, Price C, Brown T A. The kinship of two 12th Dynasty mummies revealed by ancient DNA sequencing. J Arch Sci 2018; 17: 793-797.

${ }^{45}$ Sivagami A V, Rao A R, Varshney U. A simple and cost-effective method for preparing DNA from the hard tooth tissue, and its use in polymerase chain reaction amplification of amelogenin gene segment for sex determination in an Indian population. Forensic Sci Int 2000; 110: 107-115.

${ }^{46}$ Wandeler P, Smith S, Morin P A, Pettifor R A, Funk S M. Patterns of nuclear DNA degeneration over time - a case study in historical teeth samples. Mol Ecol 2003; 12: 1087-1093.

${ }^{47}$ Cobb J C. Ancient DNA recovered by a non-destructive method. Anc Biomol 2002; 4: 169-172.

${ }^{48}$ Alakoç Y D, Aka P S. "Orthograde entrance technique" to recover DNA from ancient teeth preserving the physical structure. Forensic Sci Int 2009; 188: 96-98.

${ }^{49}$ Higgins D, Austin J J. Teeth as a source of DNA for forensic identification of human remains: A Review. Sci Justice 2013; 53: 433-441.

${ }^{50}$ Stevanovitch A, Gilles A, Bouzaid E et al. Mitochondrial DNA sequence diversity in a sedentary population from Egypt. Ann Hum Genet 2004; 68: 23-39.

${ }^{51}$ Schuenemann V J, Peltzer A, Welte B et al. Ancient Egyptian mummy genomes suggest an increase of SubSaharan African ancestry in post-Roman periods. Nat. Commun 2017; 8: 15694.
} 